\title{
PENGERTIAN DAN SEJARAH \\ MUNCULNYA LAISSEZ FAIRE
}

\author{
Ahmad Mahdi Bunayya (90100118007) \\ Mahasiswa Jurusan Ekonomi Islam UIN Alauddin Makassar \\ Email : mahdibuna@gmail.com
}

\section{A. Pengertian Laissez Faire}

Laissez- faire merupakan suatu frasa bahasa Perancis yang berarti" perkenankan berlangsung"( secara harafiah" perkenankan berbuat"). Sebutan ini bersumber dari diksi Perancis yang dipergunakan awal kali oleh para psiokrat pada ratus tahun ke 18 selaku bentuk perlawanan terhadap intervensi pemerintah dalam perdagangan. Pada style kepemimpinan ini pemimpin tidak mengetuai, ia cuma membiarkan kelompoknya berbuat semaunya sendiri. Pemimpin tidak berpartisipasi sedikitpun dalam aktivitas kelompoknya. Seluruh pekerjaan dikerjakan oleh bawahannya. Serta pemimpin dalam perihal ini selaku simbol ataupun lambang lembaga. ${ }^{1}$

Kepemimpinannya dijalankan dengan membagikan kebebasan kepada seluruh anggota dalam menetapkan keputusan serta melaksanakannya bagi kehendak tiaptiap. Jenis kepemimpinannya ini ialah kebalikan dari jenis kepemimpinan otoriter. Kepemimpinan dijalankan dengan membagikan kebebasan penuh pada orang- orang yang dipimpim dengan mengambil keputusan serta melaksanakan aktivitas bagi kehendak serta kepentingan tiap- tiap, baik secara perorangan ataupun kelompokkelompok kecil. Pemimpin cuma memfungsikan dirinya selaku penasehat. ${ }^{2}$

\section{B. Sejarah Munculnya Laissez Faire}

Pada abad ke 19 di Inggris, laissez- faire mempunyai pengikut yang sedikit tetapi kokoh semacam Liberalis Manchester semacam Richard Cobden serta Richard Wright. Tahun 1867, ini berujung pada konvensi perdagangan leluasa ditandatangani antara Britania serta Prancis, sehabis sebagian dari perjanjian ini ditandatangani bersama negara- negara Eropa yang lain. Koran The economics didirikan tadinya pada tahun 1843, serta perdagangan leluasa didiskusikan dalam suatu tempat berjulukan The Cobden Club, didirikan setahun sehabis kematian Richard Cobden, tahun 1866.

\footnotetext{
${ }^{1}$ Muhammad Zamroji, "The Nature Of Leadership," ZAHRA: Research and Tought Elementary School of Islam Journal 1, no. 2 (2020): 46-57.

${ }^{2}$ lbid.
} 
Bagaimanapun, laissez- faire tidak sempat jadi doktrin negeri manapun, serta diakhir seribu 8 ratusan, negara- negara Eropa malah menganut sistem intervionisme serta proteksionisme lagi. Prancis contohnya, mulai membatalkan kesepakatannya dengan negeri Eropa lain tahun 1890. Proteksionisme Jerman diawali( lagi) pada Desember 1878 pesan dari Bismarck, berujung pada tarif yang keras serta besar tahun $1879 .^{3}$

Sehabis Perang Dunia Kedua, pemikiran laissez- faire dibangkitkan kembali lewat Austrian School serta Chicago School, serta pemikir liberal semacam Ludwig von Mises, Freidrich Hayek serta Milton Friedman, yang berkomentar jika Dunia Leluasa didefinisikan oleh kebebasan itu sendiri, kemudian penduduknya wajib mempunyai kebebasan ekonomi secara penuh. Hong Kong ialah teritori awal yang memakai kebijakan laissez- faire di masa ini, menjajaki jalur tersebut semenjak 1960an. Jerman mengenakan ini, dengan sokongan koalisi antara Demokratik Kristen serta Demokrat Sosial, yang dijuluki dengan Ekonomi pasar sosial, yang merestorasi ulang ekonomi Jerman yang sirna sebab perang dengan membiarkan harga mengambang leluasa. $^{4}$

Setelah itu pada tahun 1970 serta 1980, ilham dari Chicago School meresonansi dalam kebijakan ekonomi di Chili, Reaganomi Ronald Reagan, serta kebijakan privatisasi dari Margaret Tatcher. Kembalinya ekonomi pasar sehabis Perang Dunia Kedua masih jauh dari ketentuan laissez- faire. Amerika Serikat, pada tahun 1980- an misalnya, berkecendrungan melindungi industri mobil dengan pembatasan ekspor" sukarela" dari Jepang. ${ }^{5}$ Berbeda sistem ekonomi sosialis yang dibesarkan oleh Karl Max menghendaki maksimalisasi peran negara. Negara harus menguasai segala zona ekonomi buat membetulkan keadilan kepada rakyat mulai dari penciptaan, komsumsi sampai mendistribusikannya kembali kepada buruh, sehingga mereka pula menikmati hasil usaha. ${ }^{6}$

\footnotetext{
${ }^{3}$ Antonia Taddei, London clubs in the late nineteenth century (University of Oxford Oxford, UK, 1999).

${ }^{4}$ Robert W Crandall, "The effects of US trade protection for autos and steel," Brookings Papers on Economic Activity 1987, no. 1 (1987): 271-88.

${ }^{5}$ Ibid.

${ }^{6}$ Idris Parakkasi dan Kamiruddin Kamiruddin, "Analisis Harga Dan Mekanisme Pasar Dalam Perspektif Islam," Laa Maisyir: Jurnal Ekonomi Islam 5, no. 1 (2018).
} 


\section{DAFTAR PUSTAKA}

Crandall, Robert W. "The effects of US trade protection for autos and steel.” Brookings Papers on Economic Activity 1987, no. 1 (1987): 271-88.

Parakkasi, Idris, dan Kamiruddin Kamiruddin. “Analisis Harga Dan Mekanisme Pasar Dalam Perspektif Islam.” Laa Maisyir: Jurnal Ekonomi Islam 5, no. 1 (2018).

Taddei, Antonia. London clubs in the late nineteenth century. University of Oxford Oxford, UK, 1999.

Zamroji, Muhammad. "The Nature Of Leadership." ZAHRA: Research and Tought Elementary School of Islam Journal 1, no. 2 (2020): 46-57. 